\title{
SUSTAINABLE COMPETITIVENESS AS A NEW ECONOMIC CATEGORY - DEFINITION AND MEASUREMENT ASSESSMENT
}

\author{
Katarzyna CHEBA (D) ${ }^{*}$, Iwona BĄ ${ }^{\mathbb{D} 1}$, \\ Katarzyna SZOPIK-DEPCZYŃSKA (D2 \\ ${ }^{1}$ Department of Applied Mathematics in Economics, Faculty of Economics, \\ West Pomeranian University of Technology, Szczecin, Poland \\ ${ }^{2}$ Department of Corporate Management, Institute of Management, \\ University of Szczecin, Szczecin, Poland
}

Received 10 January 2020; accepted 17 July 2020

\begin{abstract}
The main purpose of the paper is to assess the level of EU countries' ability to compete in a sustainable manner and to compare these results with achievements in the area of sustainable competitive position. In the paper, the definition of the new economic category - sustainable competitiveness and its main components: sustainable competitive capacity and sustainable competitive position, as well as these new terms' measurement proposal were presented. The study is also an attempt to the exploration of relationship existing between those categories. For this purpose, the selected statistical methods were applied. The taxonomic measure of development as well as the correlation coefficients, were used to measure the multilevel relationship between those considered areas. Until now, those categories were presented only in the context of examining the countries' ability to compete sustainably. However, the aspects of sustainable competitive position have been completely ignored. That's why it should be emphasized that this kind of investigation is a novelty in the area of sustainable competitiveness. The research results confirmed the existence of relationship between the various areas that consist to the holistic concept of sustainable competitiveness. These relationships are not always strong though and this is the crucial fact for further research in this area.
\end{abstract}

Keywords: sustainable development, sustainable competitive capacity, sustainable competitive position, sustainable competitiveness, strength of relation, typological groups, similarity of development

JEL Classification: C38, F02, Q01.

\section{Introduction}

In the literature on the subject (e.g. Lu \& Sexton, 2008; Borys \& Czaja, 2009), it is pointed out that the current stage of the evolution of the idea of sustainable development is primarily its concretization. The aim of that action is to develop the theoretical basis of a new

*Corresponding author. E-mail: katarzyna.cheba@zut.edu.pl

Copyright (c) 2020 The Author(s). Published by Vilnius Gediminas Technical University

This is an Open Access article distributed under the terms of the Creative Commons Attribution License (http://creativecommons. org/licenses/by/4.0/), which permits unrestricted use, distribution, and reproduction in any medium, provided the original author and source are credited. 
paradigm of development and its integration with other areas of research, including such directions as: sustainable transport (Ajanovic, 2014; Vashisth et al., 2018), sustainable agriculture (Velten et al., 2015), sustainable logistics, sustainable cities (Scheurer, 2001; Čiegis et al., 2005), social sustainability (Littig \& Griessler, 2005), corporate sustainability (Calabrese et al., 2019), sustainable finances (Zioło et al., 2019) as well as sustainable competitiveness (Schwab \& Sala-i-Martin, 2012; Aiginger et al., 2013; Corrigan et al., 2014; Aiginger \& Vogel, 2015; Cheba, 2019) and even sustainable law (Schrijver, 2008) and environmental (green) marketing philosophy (Grundey, 2008). It is worth noting that there are different ways to integrate and include sustainable development into research in other fields of science. The new definitions quite clearly indicate their separateness and differences in terms of the descriptions of sustainable development presented in large numbers of publications (e.g. Balkytè \& Tvaronavičienè, 2011; Cheba \& Bąk, 2019; Zioło et al., 2019). On the other hand, the proposed measurement concepts are usually limited to separate a set of indicators describing a given area, taking into account their sustainability, e.g. in finance those are the indicators describing the financing aspects of eco-innovation and green investments, in agriculture - indicators describing e.g. organic farming, in transport - indicators regarding e.g. electromobility etc. According to the authors of this paper, this approach to measuring various types of sustainable areas is insufficient. Moreover, integrating sustainable development into other areas of research is a much more complicated process than is commonly practiced (Cheba, 2019; Cheba \& Szopik-Depczyńska, 2019). First of all, attention should be paid to the differences between the definitions of the basic term, which is sustainable development and the proposed measurement proposals presented in the literature. It is a fairly common practice, despite clearly distinguishing the definitions of sustainable development areas as: economic, social or environmental. This is the assessment of the achieved level of sustainable development based on one synthetic measure. This also means that despite the use of many different indicators to assess this level, taken together or divided into groups, the end result is one synthetic measure that determines which country is more sustainable (Hämäläinen, 2003; Rogalska, 2018; Thalassinos et al., 2019). Meanwhile, according to the proposed definitions, sustainable development is a much more complex term and this should also be reflected in the proposed measurement concepts. This approach was also considered in this paper concerning the definition and measurement of sustainable competitiveness, which is one of the examples of integrating sustainable development into research in different areas.

According to the authors, in this case, it is necessary to define terms such as: sustainable competitive ability or ability to compete in a sustainable manner and sustainable position of competitiveness. Considering them together will fully describe sustainable competitiveness. In the paper, the definitions of these terms, the relationship between them and the measurement proposals as the result of the analysis are presented in macroeconomic terms of analyzing the results achieved by EU countries. The proposed definitions and the described measurement assessment is a new approach to research dedicated to the possibilities of including sustainable development in the studies on the competitiveness of the economy. The main purpose of the paper is therefore to assess the level of the ability of the economies of selected countries (in this case the European Union Member States) to compete in a sustainable manner and to compare these results with the achievements in the area of sustainable competitive position. It should be emphasized that sustainable development and international competitiveness of the economies are currently one of the most frequently raised prob- 
lems, important for further development of countries in the world. Each of them, considered separately, is an important area of scientific considerations and examinations, leading to the decisions regarding future strategic directions of national economies' development. The layout of this paper therefore contains the introduction presents the main purpose of the work and explains the most important authors' motivations to conduct research in the area of relationship between sustainable development and competitiveness. Further, the paper contains the literature review on the formulation and measurement of the new research concept related to the inclusion of sustainable development in competitiveness research, especially at the macroeconomic level, i.e. in relation to the economies of the countries. The next part discusses the statistical data used in the paper as well as the description of the research procedure. Finally, the paper presents the results of the research, the discussion and conclusions of conducted research.

\section{Sustainable competitiveness at the national level - the definition and measurement proposal}

In the literature on the subject sustainable competitiveness on the national level is defined, for example, as "the ability to generate and maintain the well-being and a decent standard of living for all citizens without reducing the future ability to maintain or increase the current level of wealth" (Aiginger et al., 2013). Corrigan et al. (2014) define "sustainable competitiveness as the set of institutions, policies and factors that make a nation productive over the longer term while ensuring social and environmental sustainability". Similar definitions, in which it is proposed to extend current methods of describing the international competitiveness of the economy to the social and environmental dimension of this competition, can also be found in Balkyte and Tvaronavičienè (2011), Aiginger et al. (2013), Cheba (2019). The basis of these definitions is the belief that, in the long-run, not only economic but also human development and ecological sustainability are important ingredients for high productivity and a prosperous society (Bilbao-Osorio et al., 2013).

It should be noted, however, that the current proposals to define and measure this new term have been limited to include areas describing sustainable development in the definitions traditionally used to describe the competitiveness of countries in the world (e.g. Lall, 2001; Berger, 2008; Rutkauskas, 2008; Atif et al., 2012; Huggins et al., 2013; Aiginger \& Vogel, 2015).

The relationship between competitiveness, social conditions and environmental responsibility is usually presented as follows (Figure 1).

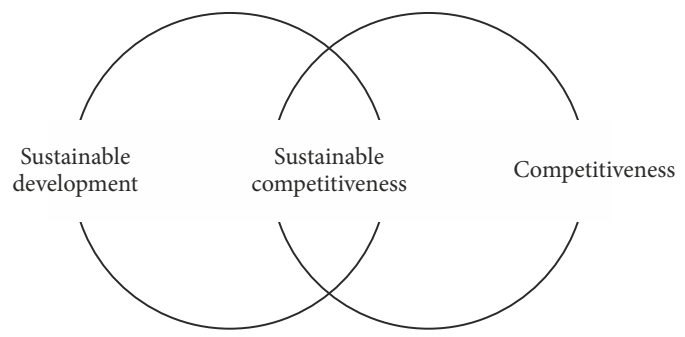

Figure 1. The main components of the sustainable competitiveness (source: Balkytė \& Tvaronavičienè, 2011) 
However, at the measurement stage this only involved expanding the existing collections to include indicators describing the social and environmental area. According to the authors, this approach is not sufficient when defining and measuring sustainable competitiveness. In the case of competitiveness (and this also applies to a sustainable approach to defining and measuring this term), it is necessary to define: the ability to compete sustainably and the achievement of a sustainable competitive position that form the overall concept of sustainable competitiveness.

The sustainable competitive capacity or ability to compete sustainably at the national level can be defined as (Cheba, 2019) "the ability of a given country to compete sustainably in the international arena, taking into account not only the economic dimension of this competition, but also the social and environmental dimensions". Sustainable competitive position achieved by countries can be described as (Misala, 2011): "the state and changes in the share of a given economy in the broadly understood international turnover" (Cheba, 2019) "implemented with care for the environment and society". Both of these concepts constitute the definition of sustainable competitiveness, which can be defined as the sum of the country's ability to compete in a sustainable manner and its competitive position. It should be noticed that good results in terms of ability of sustainable competitiveness may not necessarily mean a high balanced competitive position. This also means different ranges of measures used to measure both dimensions. Defining these two dimensions also makes it possible to distinguish the concept of sustainable development from the definition of sustainable competitiveness. Graphically, it can be presented as follows (Figure 2):

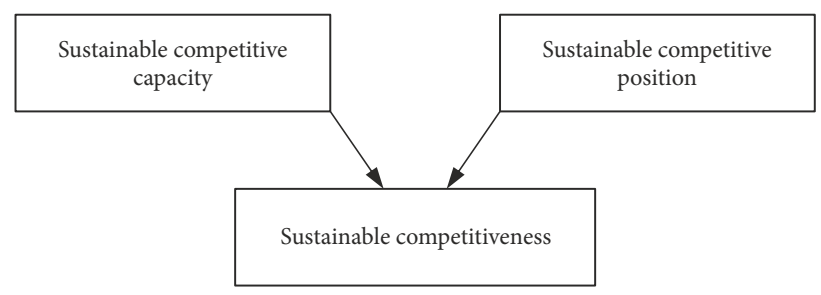

Figure 2. Relations between sustainable: capacity, position and competitiveness of national economy (source: Cheba, 2019)

Although the literature on the subject (e.g. Stiglitz et al., 2010; Blanke et al., 2011; Ketels, 2016) clearly indicates that sustainable development is not the same as sustainable competitiveness - this has been contradicted by current measurement proposals for this new research area. As already mentioned, limited to the inclusion of indicators describing sustainable development in the social and environmental field in the indicators traditionally used to measure competitiveness. It should be noted that this will not be a traditional approach in which one taxonomic measure is set taking into account the different governance of sustainable development (Leonard et al., 2006; Siche et al., 2008; Kondyli, 2010; Mori \& Christodoulou, 2012; Szopik-Depczyńska et al., 2018; Guijarro \& Poyatos, 2018). According to the authors, 
changes are also needed in this case to examine the relationship between these orders. If we assume that, in accordance with the strong principle of sustainability of development, replacing the loss of a resource, e.g. forests, can only take place by supplementing this resource, it will not be legitimate to say that the results in terms of sustainable development are the average obtained in the areas creating this development, i.e. ; social, environmental or economic. The authors of this work incline to the view that it is more reasonable to consider the relationship between the various orders that create sustainable development. This means that a country that achieves high results in each of the distinguished governance of sustainable development will be considered the most sustainable. In the case of separation of the ability to compete and balanced competitive position proposed by the authors, the indicators used to assess progress in implementing the idea of sustainable development can be used as a basis for measuring sustainable competitiveness of economy. However, the work proposes to use them only at the stage of assessing the economy's ability to compete in a sustainable way, assuming that the overall concept of measuring sustainable competitiveness should also include references to sustainable competitive position. If we assume that economies achieving a higher level of sustainable development will also have greater capacity for sustainable competition, then the indicators used to measure progress in the implementation of the 2030 Agenda (The 2030 Agenda for Sustainable Development) can be used to measure these capabilities.

As an effect of the changes proposed by the authors, regarding both the definition and measurement of sustainable competitiveness, following research questions had been constituted:

1. How strong is the relationship between various areas describing the ability to compete sustainably as well as sustainable competitive position of the EU countries?

2. Were there any changes in each of the areas of sustainable competitiveness due to their results in the structure of ordering EU countries in 2008 and 2016?

3. For which countries the similarity of development in each area considered in holistic concepts of sustainable competitiveness can be observed?

In order to achieve the responses to those formulated questions, the research procedure consisting of several stages was used. In the first step, EU countries were ordered due to their level of sustainable competitive: capacity and position. Then, in the next one, EU countries were classified in terms of similarity in each areas considered separately as well as together. Following the so-called strong principle of sustainability, which assumes the complementarity of the selected areas and the possibility of replacing the loss of the resource only within the area to which it was classified, it was adopted that all highlighted areas are equally important. Therefore in the paper, the countries that have achieved similar results in any of the highlighted areas of sustainable competitive: capacity and position will be recognized as similar ones. To classify countries according to these assumptions, the multi-criteria taxonomy method was used, which was described, among others in works: (Malina, 2004; Cheba \& Bąk, 2019). 


\section{Research procedure}

\subsection{Selection of diagnostic indicators}

In the paper two sets of diagnostic indicators were used. First one is related to the area of sustainable competitive capacity. For this purpose the basis of empirical analysis are indicators used by the European Commission to monitor the progress in the implementation of the "The 2030 Agenda for Sustainable Development" in the European Union. These indicators, in accordance with the adopted assumptions, are used in the work to assess the ability of these countries to compete in sustainable manner. In the compilations provided by Eurostat (2018) there is currently 100 indicators describing 17 goals of 2030 Agenda (51 of them are a part of a global list of indicators of the United Nations - the UN, the remaining ones were chosen in such a way as to enable monitoring the direction of changes in accordance with the relevant policies and initiatives of the EU). Whereas in the paper, these indicators were assigned to four areas describing the ability of EU countries to compete in a sustainable manner in the economic, social, environmental and institutional-political dimension, which was separated from the indicators describing the social order of sustainable development. The decision to separate this order was primarily influenced by its particular importance for the functioning, development and integration of European Union Member States.

To assess the current position of EU countries in terms of sustainable competitive position, indicators that the OECD (Organization for Economic Co-operation and Development) uses to monitor progress in the area of green growth in the field of: technology and innovation patents were used (Shrivastava, 1995; Foxon et al., 2005; Del Río et al., 2016).

Two years were selected to study the changes taking place in the specified sustainable competitiveness. The first of was 2008 - immediately after the outbreak of the global economic crisis, after the collapse of many trends in the world economy in 2007, a gradual return to the current growth path in many countries of the world is observed (Cheba \& Bąk, 2019) and due to for full data availability for all analysed indicators - 2016. Authors decided that comparing the results obtained by individual EU Member States in those two years would allow to identify the direction of changes in the structure of the obtained results. Moreover, because authors' main attention was directed to the study of changes in the structure of ordering of EU countries, the results obtained in the analysed years were considered separately.

The results of the analysis presented in the work do not include Croatia, which became a member of the European Union on July 1, 2013 and for which deficiencies in data for years before its accession to the European Community were identified.

In the next step, after checking the completeness of data, 36 indicators out of one hundred indicators obtained from Eurostat and adopted by authors to describe the sustainable competitive capacity were excluded from further analysis, mainly due to their availability only at the level of the whole of Europe or the European Union and the lack of data e.g. for indicators describing the protection of the sea in the case of countries which do not have access thereto. Four diagnostic indicators were excluded from the study due to their poor diagnostic properties; the classic coefficients of variation for these indicators were lower than $10 \%$ (Nowak, 1990). To measure the variability of indicators, other measures can also be used, e.g. the quarter, median and median coefficients using the Weber median (Młodak, 2006). 
Ultimately, the prepared set included 64 indicators, 18 of which described the economic order being the basis for assessing the sustainable capacity of EU countries in the economic area, 26 indicators related to the social order, 11 to the environmental order and 9 indicators to the institutional and political order. To the second data set, dedicated to sustainable competitive position, 6 indicators from the OECD database were selected.

Due to the fact that the study analysed indicators describing changes occurring in individual orders of sustainable development of EU countries in two periods of time (2008 and 2016), it was decided that the selection of diagnostic indicators should also take into account changes in these indicators over time. To this end, a matrix of Pearson correlation coefficients was determined for each of the analyzed periods:

$$
\mathbf{R}_{t}=\left[r_{j k t}\right],
$$

where: $r_{j k t}$ is the Pearson correlation coefficient between two indicators $X_{j}$ and $X_{k}$ in the period $t$, and $j, k=1,2, \ldots, m, t=1,2, \ldots, \tau$.

Based on the matrices created in this way, the diagnostic indicators were selected separately for each year. The inverse correlation coefficient matrix method was used (Młodak, 2006), in which the basis is an inverse matrix to $\mathbf{R}_{t}$ matrix:

$$
\mathbf{R}^{-1}=\left[\begin{array}{llll}
\tilde{r}_{11} & \tilde{r}_{12} & \ldots & \tilde{r}_{1 m} \\
\tilde{r}_{21} & \tilde{r}_{22} & \ldots & \tilde{r}_{2 m} \\
\ldots & \ldots & \ldots & \ldots \\
\tilde{r}_{m 1} & \tilde{r}_{m 2} & \ldots & \tilde{r}_{m m}
\end{array}\right],
$$

In this matrix:

$$
\tilde{r}_{j k}=\frac{(-1)^{j+k} \operatorname{det}\left(\mathbf{R}_{k j}\right)}{\operatorname{det}(\mathbf{R})},
$$

where: $\mathbf{R}_{k j}$ - the reduced matrix after removing $j$-th row and $k$-th column, $j, k=1,2, \ldots, m$, $\operatorname{det}\left(\mathbf{R}_{k j}\right)$ and $\operatorname{det}(\mathbf{R})$ - the determinants of the matrix $\mathbf{R}_{k j}$ and $\mathbf{R}$, respectively.

The diagonal elements of the matrix $\mathbf{R}^{-1}$ take values from the interval $[1, \infty)$. In the situation when the considered indicators do not create many exact interdependencies, its diagonal elements are defined as Variance Inflation Factor - VIF, which are determined for given indicators in comparison to others. These coefficients are determined as follows (Neter et al., 1985):

$$
r_{j j}^{-1}=V I F_{j}=\frac{1}{1-R_{j}^{2}},
$$

where: $R_{j}$ - regression determination coefficient of $j$-th variable relative to the others, $j=1$, $2, \ldots n, n-$ the number of variables in the model after variation verification.

However, if these elements are too large (it is usually assumed that these values are greater than 10), this means a faulty numerical conditioning of $\mathbf{R}^{-1}$ matrix, i.e. excessive correlating of a given feature with other ones. If it concerns only one feature with this property, it can be eliminated. Neverthelss, it should be noted that the simultaneous elimination of a greater number of such indicators may lead to an excessive depletion of the information resource of the model being built. In this situation, in the literature on the subject (Młodak et al., 2016) it is recommended to eliminate only some of them in such a way that the diagonal 
elements of the inverted matrix of the correlation coefficients of the remaining indicators are sufficiently low. These indicators can be eliminated gradually (Cheba, 2019), similarly as in the Hellwig parametric method (1968). This means, removing first the indicators for which the corresponding diagonal elements of the inverted correlation coefficient matrix are the highest (above 10) and re-determining this matrix for the remaining indicators as follows (Młodak, 2006):

1. First, the maximum level $\tilde{\boldsymbol{r}}$ (critical value) which the diagonal elements of the matrix $\mathbf{R}^{-1}$ can take. Most often this value is set at $\tilde{\boldsymbol{r}}=10$.

2. In the next step, the inverse correlation matrix $\mathbf{R}^{-1}$ identifies the elements $\tilde{r}_{j k}$, $\boldsymbol{j} \in\{1,2, \ldots, \boldsymbol{m}\}$ that satisfy the inequality:

$$
r_{j j}^{-1}=V I F_{j}=\frac{1}{1-R_{j}^{2}} .
$$

Matrix elements that meet the above condition correspond to indicators that cause faulty numerical conditioning of the matrix $\mathbf{R}$, in particular when exceeding the adopted threshold value is significant.

Then, the inverse correlation coefficient matrix $\mathbf{R}^{-1}$ is reduced by plotting the highlighted column and row for which the diagonal elements of the inverse correlation coefficient matrix are the highest. In this way, the so-called reduced inverse correlation coefficient matrix is obtained. The operations described in points $2-3$ are repeated until all the indicators causing the defective numerical conditioning of the matrix $\mathbf{R}$ are removed. The proposed method allows achieving the integrity of the taxonomic model in terms of both direct (observed on the basis of correlations) as well as indirect connections occurring between the considered indicators (Malina, 2004; Młodak, 2006).

As a result of adopted procedure, the final data set was created, including 41 indicators in the area of sustainable competitive capacity and 4 indicators describing the sustainable competitive position.

\subsection{Statistical data}

Due to the fact that the selection of diagnostic indicators for the research was conducted separately for data from the years 2008 and 2016, the final set was created by those indicators that were existed in both analyzed years. The result of applying the proposed procedure for the selection of diagnostic indicators is five sets of diagnostic indicators presented in Tables $1-5$. The $x_{i . j}$ symbol is assigned to each of the highlighted indicators, where $i$ is the number of the area in which the feature is located, while $j$ - is the number of the feature. Moreover, their influence on the analyzed phenomenon was indicated through the classification of each attribute to a set of characteristics stimulating development in a given area (symbol $S$ ) or destimulating this development (symbol $D$ ).

11 diagnostic indicators ( 4 stimulants and 7 destimulants) were qualified to describe the economic area of sustainable competitive capacity (ESC). This group includes indicators describing the economic development of the EU countries (indicators: $x_{1.1 S}$ and $x_{1.2 D}$ ), employment and working conditions $\left(x_{1.3 D}-x_{1.6 D}\right)$, innovation $\left(x_{1.7 S}\right.$ and $\left.x_{1.8 S}\right)$, the environmental impact of the economy $\left(x_{1.9 D}\right.$, economy on society $\left(x_{1.10 D}\right)$ and agriculture $\left(x_{1.11 S}\right)$. 
Table 1. Diagnostic indicators describing the economic area of sustainable competitive capacity

\begin{tabular}{|c|l|}
\hline Symbol & \multicolumn{1}{|c|}{ Indicator } \\
\hline$x_{1.1 S}$ & $\begin{array}{l}\text { agricultural factor income per annual work unit (AWU), (according to prices from 2010, } \\
\text { in Euro per annual unit of work) }\end{array}$ \\
\hline$x_{1.2 D}$ & general government gross debt, \% of GDP \\
\hline$x_{1.3 D}$ & inactive population due to caring responsibilities, \% of inactive population aged 20 to 64 \\
\hline$x_{1.4 D}$ & young people neither in employment nor in education, (\% of population aged 15 to 29) \\
\hline$x_{1.5 D}$ & involuntary temporary employment, \% of employees aged 20 to 64 \\
\hline$x_{1.6 D}$ & people killed in accidents at work, number per 100 000 employees \\
\hline$x_{1.7 S}$ & government support to agricultural research and development, Euro per capita \\
\hline$x_{1.8 S}$ & gross domestic expenditure on R\&D, \% of GDP \\
\hline$x_{1.9 D}$ & volume of freight transport relative to GDP, index (2005 = 100) \\
\hline$x_{1.10 D}$ & share of labour taxes in total tax revenues, \% \\
\hline$x_{1.11 S}$ & area under organic farming, \% of utilised agricultural area \\
\hline
\end{tabular}

However, the next group - describing the social area of sustainable competitive capacity - 14 diagnostic indicators were included (mainly destimulants) describing poverty and social exclusion (indicators: $\left.x_{2.1 D}-x_{2.6 D}\right)$, lifestyle and public health $\left(x_{2.7 D}\right)$, education and development $\left(x_{2.8 D}, x_{2.9 S}, x_{2.10 S}\right)$, the level and the quality of life $\left(x_{2.11 D}\right)$ and public safety $\left(x_{2.12 D}, x_{2.13 D}, x_{2.14 D}\right)$.

Table 2. Diagnostic indicators describing the social area of sustainable competitive capacity

\begin{tabular}{|c|l|}
\hline Symbol & \multicolumn{1}{|c|}{ Indicator } \\
\hline$x_{2.1 D}$ & $\begin{array}{l}\text { people living in households with very low work intensity, \% of persons under 60 living in } \\
\text { households with very low work intensity, i.e. those in which adults (18-59 years old) have } \\
\text { worked less than 20\% of their total work potential in the past year }\end{array}$ \\
\hline$x_{2.2 \mathrm{D}}$ & housing cost overburden rate, \% of population \\
\hline$x_{2.3 \mathrm{D}}$ & $\begin{array}{l}\text { population living in a dwelling with a leaking roof, damp walls, floors or foundation or } \\
\text { rot in window frames of floor, \% of population }\end{array}$ \\
\hline$x_{2.4 \mathrm{D}}$ & population unable to keep home adequately warm, \% of population \\
\hline$x_{2.5 \mathrm{D}}$ & long term unemployment rate, \% of active population \\
\hline$x_{2.6 \mathrm{D}}$ & relative median at-risk-of-poverty gap, \% distance to poverty threshold \\
\hline$x_{2.7 \mathrm{D}}$ & suicide rate, number per 100 000 persons \\
\hline$x_{2.8 \mathrm{D}}$ & early leavers from education and training, \% of population aged 18 to 241 \\
\hline$x_{2.9 S}$ & tertiary educational attainment, \% of population aged 30 to 34 \\
\hline$x_{2.10 S}$ & adult participation in learning, \% of population aged 25 to 64 \\
\hline$x_{2.11 \mathrm{D}}$ & population living in households considering that they suffer from noise, \% of population \\
\hline$x_{2.12 \mathrm{D}}$ & $\begin{array}{l}\text { death rate due to homicide, number per } 100 \text { 000 persons (standardized death rates } \\
\text { calculated on the basis of the standard European population) }\end{array}$ \\
\hline$x_{2.13 \mathrm{D}}$ & population reporting occurrence of crime, violence or vandalism, \% of population \\
\hline$x_{2.14 \mathrm{D}}$ & people killed in road accidents, rate, number per 100000 persons \\
\hline
\end{tabular}

\footnotetext{
1 According to the European Commission, completing education too early consists in students obtaining at most lower secondary education. The term "early leavers" is also used to mean "early leavers in education and training".
} 
8 diagnostic indicators ( 3 stimulants and 5 destimulants) were qualified to describe the environmental area of sustainable competitive capacity (ENSC), which can be divided into the following characteristics: energy use $\left(x_{3.1 D}, x_{3.2 S}, x_{3.3 D}\right.$, and $\left.x_{3.4 S}\right)$, air quality $\left(x_{3.5 D}, x_{3.6 D}\right)$, waste management $\left(x_{3.7 S}\right)$ and the impact of the economy on the environment $\left(x_{3.8 D}\right)$.

Table 3. Diagnostic indicators describing the environmental area of sustainable competitive capacity

\begin{tabular}{|c|l|}
\hline Symbol & \multicolumn{1}{|c|}{ Indicator } \\
\hline$x_{3.1 D}$ & primary energy consumption, million tonnes of oil equivalent (TOE) \\
\hline$x_{3.2 S}$ & share of renewable energy in gross final energy consumption, $\%$ \\
\hline$x_{3.3 D}$ & energy dependence ${ }^{2}, \%$ of imports in total energy consumption \\
\hline$x_{3.4 S}$ & energy productivity, PPS $^{3}$ per kilogram of oil equivalent \\
\hline$x_{3.5 D}$ & ammonia emissions from agriculture, kilograms per hectare \\
\hline$x_{3.6 D}$ & greenhouse gas emissions - tonnes per capita \\
\hline$x_{3.7 S}$ & recycling rate of municipal waste, $\%$ of total waste generated \\
\hline$x_{3.8 D}$ & shares of environmental taxes in total tax revenues, $\%$ of total taxes \\
\hline
\end{tabular}

In turn, 8 diagnostic features (stimulants only) were qualified to the set of diagnostic features describing institutional and political area of sustainable competitive capacity (IPSC), which describe involvement and participation $\left(x_{4.15}-x_{4.35}\right)$, cohesion policy $\left(x_{4.45}, x_{4.55}\right)$ and global partnership $\left(x_{4.6 S}, x_{4.75}, x_{4.8 S}\right)$.

Table 4. Diagnostic indicators describing the institutional and political area of sustainable competitive capacity

\begin{tabular}{|c|l|}
\hline Symbol & \multicolumn{1}{|c|}{ Indicator } \\
\hline$x_{4.15}$ & seats held by women in national parliaments, \% of seats \\
\hline$x_{4.25}$ & seats held by women in national governments, \% of seats \\
\hline$x_{4.35}$ & $\begin{array}{l}\text { positions held by women in senior management positions, board members, \% of } \\
\text { positions }\end{array}$ \\
\hline$x_{4.4 S}$ & general government total expenditure on law courts, Euro per inhabitant \\
\hline$x_{4.55}$ & population with confidence in EU institutions: European Parliament \% of population \\
\hline$x_{4.65}$ & population with confidence in EU institutions: European Central Bank, \% of population \\
\hline$x_{4.75}$ & official development assistance as share of gross national income, \% \\
\hline$x_{4.85}$ & EU imports from developing countries by country income groups, million EUR per capita \\
\hline
\end{tabular}

However, to assess the current position of EU countries in terms of sustainable competitive position (SP), four indicators used by OECD to monitor progress in the area of green growth in the field of: technology and innovations patents were used (Table 5).

\footnotetext{
${ }^{2}$ According to Eurostat: "Energy dependence shows the extent to which the economy relies on energy imports to meet its energy needs".

${ }^{3}$ Purchasing Power Standard.
} 
Table 5. Diagnostic indicators describing the sustainable competitive position

\begin{tabular}{|c|l|}
\hline Symbol & \multicolumn{1}{|c|}{ Indicator } \\
\hline$x_{5.1 s}$ & development of environment-related technologies, \% of all technologies \\
\hline$x_{5.2 \mathrm{~s}}$ & relative advantage in environment-related technology, ratio \\
\hline$x_{5.3 \mathrm{~s}}$ & development of environment-related technologies, \% of inventions worldwide \\
\hline$x_{5.4 \mathrm{~s}}$ & development of environment-related technologies, inventions per capita \\
\hline
\end{tabular}

\subsection{Research method}

One of the assumptions adopted in the work is striving to achieve a high level of development in all areas of sustainable competitive: capacity and position. This means the need to look for methods that will allow the separation of groups of similar countries due to all the distinguished areas of this development. The solution in this case may be the use of the multicriteria taxonomy method, the description of which was presented, among others in works: Nowak (1990), Malina (2004), and Cheba (2019), Kuc-Czarnecka (2019).

For each of the distinguished classification criteria, the normalization of diagnostic indicators is carried out. In the paper the zero unitarisation method (Kukuła, 2000), was applied:

$$
\begin{aligned}
\text { for stimulant } \quad z_{i j}=\frac{x_{i j}-\min _{i} x_{i j}}{\max _{i} x_{i j}-\min _{i} x_{i j}}, \max _{i} x_{i j} \neq \min _{i} x_{i j}, \\
\text { for destimulant } z_{i j}=\frac{\max _{i} x_{i j}-x_{i j}}{\max _{i} x_{i j}-\min _{i} x_{i j}}, \max _{i} x_{i j} \neq \min _{i} x_{i j} .
\end{aligned}
$$

Indicators transformed according to formulas (6)-(7) can be used to determine the taxonomic measure of development based on the formula (Nowak, 1990):

$$
z_{i}=\frac{1}{K} \sum_{k=1}^{K} z_{i k},
$$

where: $z_{i}$ - the value of the taxonomic development measure for $i$-th object, $z_{i k}$ - normalized value of $i$-th indicator in $k$-th object, $K$ - the number of considered indicators.

The values of this measure, corresponding to individual objects (in this case EU countries), are ordered from the highest to the lowest value. Based on the results of this measure the typological groups contained countries characterized by similar level of development can be distinguished. For this purpose the following procedure can be applied:
a) group 1: $\boldsymbol{z}_{\boldsymbol{i}} \geq \overline{\boldsymbol{z}}+\boldsymbol{S}_{\boldsymbol{z}}-$ a high level of development in particular areas,
b) group 2: $\bar{z}+S_{z}>z_{i} \geq \bar{z}$ - an average level of development,
c) group 3: $\bar{z}>\boldsymbol{z}_{\boldsymbol{i}} \geq \overline{\boldsymbol{z}}-\boldsymbol{S}_{\boldsymbol{z}}-$ a low level of development,
d) group 4: $z_{i}<\bar{z}-S_{z}-$ a very low level of development. 


\section{Research results}

Table 6 compares the results of ordering and classifying EU Member States in all distinguished areas of sustainable competition: capacity and position in the years 2008 and 2016 . In this table, the value of taxonomic measure of development (column 1) and the positions in the ranking in each considered areas (column 2) were presented. The differences between the results of ordering of the EU countries in the considered years are significant. This situation applies to all analyzed areas. As an example, you can indicate countries such as: France or Germany ranked higher in the economic, social and institutional-political areas of sustainable competitive capacity and significantly lower in the case of environmental area. A similar situation is also observed in the case of other countries located in Northern and Western Europe, classified as the most economically developed EU countries and at the same time exerting greater pressure on natural environment. It means that they ability to compete sustainably in environmental area is lower than in others. However, the opposite situation can be observed e.g. in the case of: Greece and Bulgaria, as well as Poland, namely countries located in Southern and Eastern Europe. Only in the cases of Scandinavian countries: Denmark, Finland and Sweden, and also located in northern Europe - Estonia, it was observed that economic growth is separated from the pressure they exerted on the environment. These countries managed to offset the negative impact of economic development on the environment; so their ability to compete sustainably is high in every considered area. Favorable changes in the economic and environmental area (a simultaneous improvement of occupied positions) are also observed in the case of: Lithuania (the improvement of position for economic order from 17 to 12 and for environmental area from 21 to 12), Latvia (from 14 to 13 and from 10 to 3, respectively), Poland (from 26 to 21 and from 18 to 11 ), Slovakia (from 21 to 19 and from 25 to 21), Slovenia (from 13 to 10 and from 12 to 5) and Hungary (from 27 to 17 and from 20 to 17).

Similar changes were also observed for other areas of sustainable competitive capacity. A simultaneous improvement of the positions taken within the economic and social area, whose changes usually have a similar course (simultaneous increase or decrease), was observed in countries such as: Austria, Czechia, Lithuania, Latvia, Germany, Poland, Slovakia and Hungary. However, the opposite situation applies to: Cyprus, France, Spain, the Netherlands and Luxembourg. In these countries, the deterioration of positions taken in the created rankings within the economic ability to compete sustainably was associated with similar changes in the social capacity.

The comparative analysis of classification results in the analysed years shows that the largest changes in position in constructed rankings, by at least 6 places between the years 2008 and 2016 in plus and/or in minus, concerned mainly environmental area. In total, significant changes (both deterioration and improvement) were observed in 10 countries. The improvement was identified in relation to: Estonia (improvement from 9 to 2 position), Lithuania (from 21 to 12), Latvia (from 10 to 3), Poland (from 18 to 11), Romania (from 15 to 8) and Slovenia (from 12 to 5). However, the deterioration concerned: Austria (falling from position 2 to 10), Cyprus (from 17 to 23), the Netherlands (from 6 to 18) and Luxembourg (from 5 to 19$)$. 


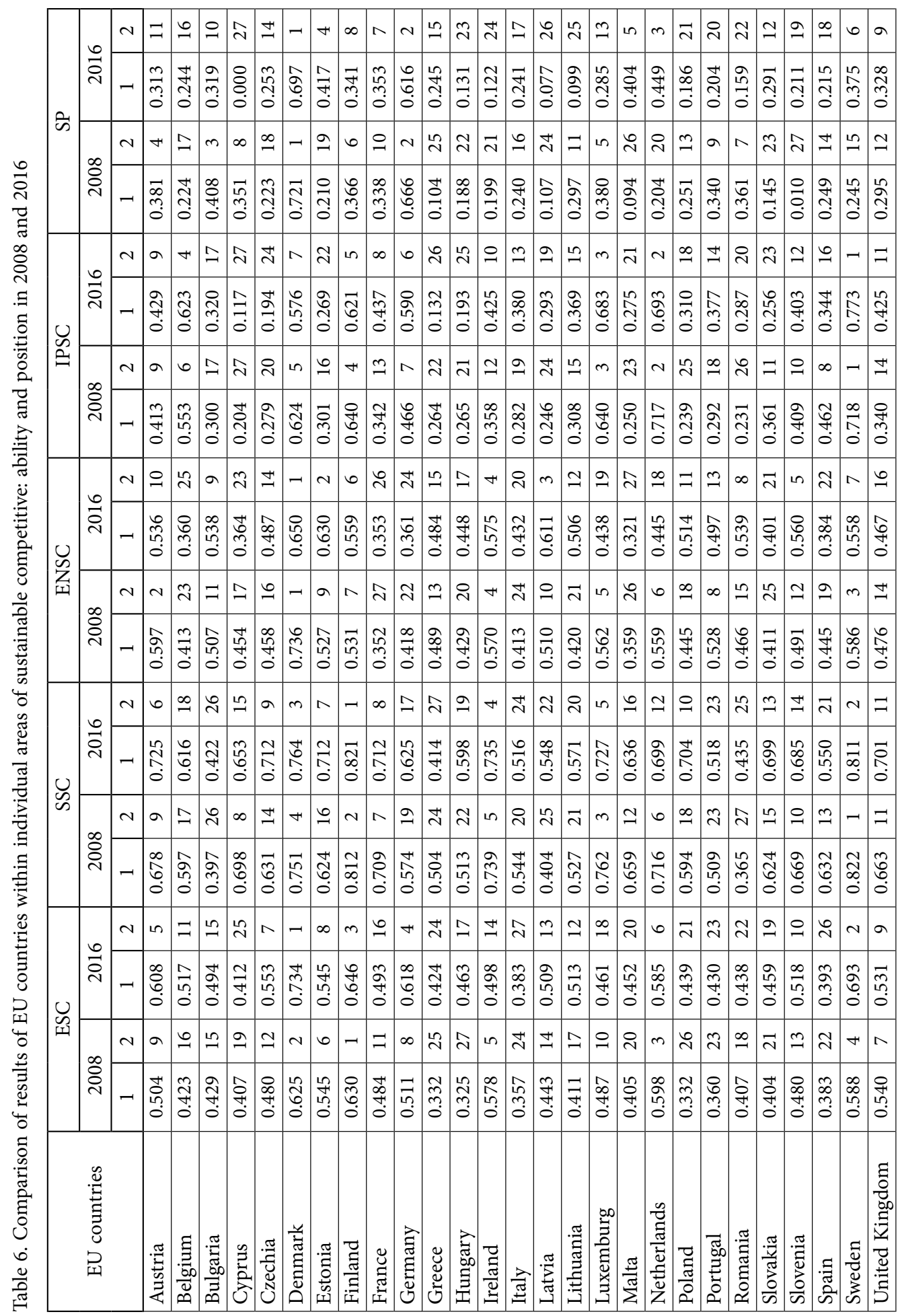


Similar changes, though less numerous, also applied to other areas. These changes were as follows:

a) for economic area of sustainable competitive capacity, the improvement concerned only Hungary (from 27 to 17), and the deterioration: Cyprus (from 19 to 25), Ireland (from 5 to 14) and Luxembourg (from 10 to 18),

b) for social area, the improvement concerned: Estonia (from 16 to 7 ) and Poland (from 18 to 10), and the deterioration: Cyprus (from 18 to 15), Spain (from 13 to 21) and the Netherlands (from 6 to 12),

c) for institutional and political area, the improvement concerned: Poland (from 25 to 18), Romania (from 26 to 20) and Italy (from 19 to 13), the deterioration: Estonia (from 16 to 22), Spain (from 8 to 16) and Slovakia (from 11 to 23).

The large differences in the results of ordering EU countries in 2008 and 2016 also apply to the last analysed area: sustainable competitive position. In this case first place is occupied by Denmark. It should be noted that, also in this case, countries from Northern and Western Europe occupied higher position in this area than countries from Southern and Eastern Europe. It is also worth paying attention to some countries that significantly improved their position in the rankings. Examples include Malta, ranked $26^{\text {th }}$ in 2008 and $5^{\text {th }}$ in 2016, and the Netherlands, which moved up from $20^{\text {th }}$ to $3^{\text {rd }}$ position. The low position of these countries in 2008 was affected by very low values of all analyzed indicators. However, not in every case high positions in rankings reflect the real situation of a given country in terms of eco-innovation level. An example would be Bulgaria with respectively: 3 and 10 places. Good achievements of this country are the result of the indicators used for the survey, which measure the intensity of a given phenomenon. If in a given country all created technologies can be treated as an environmental technologies, then even with a small number of inventions, the position of such a country will be higher.

Due to the large differences in the value of taxonomic measures of development and the positions occupied by the studied countries in the built rankings, the division of the studied objects into typological groups was also used to assess similarity of development. The results of this stage of the study are presented in Table 7 . First, attention is given to those countries that were in the same group taking into account all the analyzed areas of sustainable competitive: capacity and position. However, only one case of this type was identified and it concerned Denmark, which in all areas and years analyzed was classified into the first typological group characterized by the highest level of development.

It is also worth noting the very small number of countries qualified to the first typological group in both 2008 (Denmark and Germany) as well as in 2016 (Denmark, Germany and the Netherlands). In some cases (e.g. Sweden, Finland, Slovenia), despite good results in terms of ability to compete sustainably, designated balanced competitive positions are lower. These differences show that despite the high capacity of these countries to compete sustainably, this does not always translate into results in terms of sustainable competitive position. The results of classifications confirmed also the existing of geographical proximity of development between countries located in the same geographical part of Europe. In addition to the Scandinavian countries, very high developed in each considered areas, the geographical proximity is also visible in the case of: Western and Southern countries, very often in the same typological groups. 
Table 7. Comparison of the results due to similarity in every considered area of sustainable competitive capacity and position in 2008 and 2016

\begin{tabular}{|c|c|c|c|c|c|c|c|c|c|c|}
\hline & \multicolumn{2}{|c|}{ ESC } & \multicolumn{2}{|c|}{ SSC } & \multicolumn{2}{|c|}{ ENSC } & \multicolumn{2}{|c|}{ IPSC } & \multicolumn{2}{|c|}{ SP } \\
\hline & 2008 & 2016 & 2008 & 2016 & 2008 & 2016 & 2008 & 2016 & 2008 & 2016 \\
\hline Austria & II & I & II & II & I & II & II & II & II & II \\
\hline Belgium & III & II & III & III & III & IV & I & I & III & III \\
\hline Bulgaria & III & III & IV & IV & II & II & III & III & II & II \\
\hline Cyprus & III & IV & II & II & III & IV & IV & IV & II & IV \\
\hline Czechia & II & II & II & II & III & II & III & IV & III & III \\
\hline Denmark & I & I & I & I & I & I & I & I & I & I \\
\hline Estonia & II & II & II & II & II & I & III & III & III & II \\
\hline Finland & I & I & I & I & II & II & I & I & II & II \\
\hline France & II & III & II & II & IV & IV & III & II & II & II \\
\hline Germany & II & I & III & III & III & IV & II & I & I & I \\
\hline Greece & IV & III & III & IV & II & II & III & IV & IV & III \\
\hline Hungary & IV & III & III & III & III & III & III & IV & III & III \\
\hline Ireland & I & III & I & II & I & I & III & II & III & IV \\
\hline Italy & IV & IV & III & IV & III & III & III & III & III & III \\
\hline Latvia & III & III & IV & III & II & $\mathrm{I}$ & III & III & IV & IV \\
\hline Lithuania & III & II & III & III & III & II & III & III & II & IV \\
\hline Luxemburg & II & III & I & II & II & III & I & I & II & II \\
\hline Malta & III & III & II & III & IV & IV & III & III & IV & II \\
\hline Netherlands & I & II & II & II & II & III & I & I & III & I \\
\hline Poland & IV & III & III & II & III & II & III & III & III & III \\
\hline Portugal & IV & III & III & IV & II & II & III & III & II & III \\
\hline Romania & III & III & IV & IV & III & II & IV & III & II & III \\
\hline Slovakia & III & III & II & II & III & III & III & III & III & II \\
\hline Slovenia & II & II & II & II & II & II & II & II & IV & III \\
\hline Spain & III & IV & II & III & III & IV & II & III & III & III \\
\hline Sweden & I & I & I & I & I & II & I & I & III & II \\
\hline United Kingdom & II & II & II & II & II & III & III & II & II & II \\
\hline
\end{tabular}

The differences in the obtained classification results between individual areas are also confirmed by the received ratings of the Pearson correlation coefficients and Kendall $\tau$ in both considered years (Tables 8-9). In 2008, the lack of correlation between the values of taxonomic measures of development as well as between the results of ordering EU countries is less visible than in 2016. This year the lowest correlation coefficient ratings (Person's and Kendall's $\tau$ ) were obtained in the case of relationships between social and environmental areas of sustainable competitive capacity, as well as between every considered areas of sustainable competitive capacity and position. However, the existence of an average relationship 
can be confirmed in the case of economic and all other areas of sustainable competitive capacity, and between social, institutional and political areas. In 2016, however, there is a significant decrease in the correlation coefficients between the analyzed areas of sustainable competitive capacity. In this case, the lowest grades were obtained in the case of relationships between environmental, institutional and political as well as social and environmental areas. The estimates of correlation coefficients determined for the relationships between other areas are higher, but definitely lower than in 2008. Changes in the strength of these relationships between the analyzed years are also visible. However, the improvement of correlation is observed between the particular areas of sustainable competitive capacity and position.

Table 8. Matrix of Pearson coefficients for the results of ordering EU countries in 2008 and 2016

\begin{tabular}{|l|c|c|c|c|c|}
\hline \multicolumn{1}{|c|}{2008} & ESC & SSC & ENSC & IPSC & SP \\
\hline ESC & 1.000 & 0.666 & 0.617 & 0.688 & 0.346 \\
\hline SSC & 0.666 & 1.000 & 0.344 & 0.658 & 0.117 \\
\hline ENSC & 0.617 & 0.344 & 1.000 & 0.523 & 0.371 \\
\hline IPSC & 0.688 & 0.658 & 0.523 & 1.000 & 0.301 \\
\hline SP & 0.346 & 0.117 & 0.371 & 0.301 & 1.000 \\
\hline 2016 & ESC & SSC & ENSC & IPSC & SP \\
\hline ESC & 1.000 & 0.622 & 0.453 & 0.632 & 0.667 \\
\hline SSC & 0.622 & 1.000 & 0.141 & 0.502 & 0.352 \\
\hline ENSC & 0.453 & 0.141 & 1.000 & 0.071 & 0.047 \\
\hline IPSC & 0.632 & 0.502 & 0.071 & 1.000 & 0.528 \\
\hline SP & 0.667 & 0.352 & 0.047 & 0.528 & 1.000 \\
\hline
\end{tabular}

Table 9. Matrix of Kendall $\tau$ correlation coefficients for the results of ordering EU countries in 2008 and 2016

\begin{tabular}{|l|c|c|c|c|c|}
\hline \multicolumn{1}{|c|}{2008} & ESC & SSC & ENSC & IPSC & SP \\
\hline ESC & 1.000 & 0.493 & 0.425 & 0.476 & 0.197 \\
\hline SSC & 0.493 & 1.000 & 0.236 & 0.493 & 0.066 \\
\hline ENSC & 0.425 & 0.236 & 1.000 & 0.254 & 0.191 \\
\hline IPSC & 0.476 & 0.493 & 0.254 & 1.000 & 0.162 \\
\hline SP & 0.197 & 0.066 & 0.191 & 0.162 & 1.000 \\
\hline 2016 & ESC & SSC & ENSC & IPSC & SP \\
\hline ESC & 1.000 & 0.470 & 0.305 & 0.379 & 0.396 \\
\hline SSC & 0.470 & 1.000 & 0.185 & 0.339 & 0.276 \\
\hline ENSC & 0.305 & 0.185 & 1.000 & 0.037 & -0.060 \\
\hline IPSC & 0.379 & 0.339 & 0.037 & 1.000 & 0.345 \\
\hline SP & 0.396 & 0.276 & -0.060 & 0.345 & 1.000 \\
\hline
\end{tabular}


The differences confirm also the values of the main descriptive characteristics of the estimated taxonomic measures of development, in particular, in the case of competitive capacity, for which the coefficient of variation in the analyzed years was the highest. In the case of other areas, the assessments of coefficients of variation were lower and ranged from $16.66 \%$ (environmental area - 2008) to $44.11 \%$ (institutional and political area - 2008) (Table 10). Comparing the obtained results, a change in the sign of the asymmetry coefficient in the case of environmental area is also observed, from the right-handed in 2008 to the left-handed in 2016. This means a change in trends, i.e. the increase in the number of countries in which the obtained values of the synthetic measure are higher than the mean value.

Table 10. Summary statistics of taxonomic measure of development in: 2008 and 2016

\begin{tabular}{|l|c|c|c|c|c|c|c|c|c|c|}
\hline \multirow{2}{*}{ Summary statistics } & \multicolumn{2}{|c|}{ ESC } & \multicolumn{2}{c|}{ SSC } & \multicolumn{2}{c|}{ ENSC } & \multicolumn{2}{c|}{ IPSC } & \multicolumn{2}{c|}{ SP } \\
\cline { 2 - 12 } & 2008 & 2016 & 2008 & 2016 & 2008 & 2016 & 2008 & 2016 & 2008 & 2016 \\
\hline Mean & 0.46 & 0.51 & 0.62 & 0.64 & 0.49 & 0.48 & 0.39 & 0.40 & 0.28 & 0.28 \\
\hline Median & 0.44 & 0.50 & 0.63 & 0.69 & 0.48 & 0.49 & 0.34 & 0.38 & 0.25 & 0.25 \\
\hline Standard deviation & 0.09 & 0.09 & 0.12 & 0.11 & 0.08 & 0.09 & 0.16 & 0.18 & 0.16 & 0.15 \\
\hline Coefficient of variation [\%] & 19.92 & 17.46 & 19.48 & 17.53 & 16.97 & 18.80 & 40.65 & 44.11 & 55.32 & 54.83 \\
\hline Asymmetry & 0.20 & 0.15 & -0.10 & -0.39 & 0.13 & -0.05 & 0.31 & 0.13 & 0.21 & 0.18 \\
\hline
\end{tabular}

In 2008, higher values concerned 13 countries, and in 2016 - 15. In 2016, compared to 2008 , the number of countries with higher values of synthetic measure than the mean in the case of institutional and political area also increased (from 10 to 12) and with values lower than the mean in the case of social area (from 11 to 12) (see: Table 5).

\section{Discussion and conclusions}

The sustainable international competitiveness of national economy is a relatively new economic category presented in the literature on the subject. The basis for its definition and measurement is the theoretical and practical achievements to date in the field of sustainable development and international competitiveness of national. The current proposals formulated by various assume that the indicators applied to measure sustainable development can also be used to assess the sustainable competitiveness of economy. However, this approach does not allow identifying the differences between these categories. The paper proposes that sustainable development indicators should be used only as a basis for assessing the economy's ability to compete in a sustainable manner. On the other hand, the comprehensive assessment of sustainable competitiveness should also include the stage of assessing sustainable competitive position, assessed e.g. through the prism of exporting technologically advanced environmentally friendly solutions or indicators described the development of eco-friendly technology.

It should also be emphasized, that a direct comparison of the obtained results with the results of other available rankings, due to a different way of interpreting and measuring sustainable activity is not possible because authors have divided it into two main parts: available 
functions to compete and balanced competition. In the previous approaches to designated positions of the countries of the world, various rankings dedicated to compare the position of the designated position were based on numerical values calculated on the basis of all the considered applications. The approach proposed by the authors is based on the relationship between various areas of ability to compete and balanced competitive position. Moreover, it's possible to indicate certain regularities. In the vast wide range of rankings examining the level of EU relationships, the leading places are occupied by the Scandinavian countries. Similar results were obtained also for the methods proposed by authors. Slightly slower level of development of countries located in the south and east of Europe in relation to countries located in Northern and Western Europe is also visible, which is similar to the case of the research presented in the paper. It changes significantly the distribution of forces in Europe. It also emphasizes differences in development not only in the case of the poorer Europe Eastern countries, but of the Southern site of the continent as well, which is also losing its importance.

The article presents the original proposition to define and measure sustainable international competitiveness. The holistic concept related to this new economic category is based, among others on the study of the relationships between sustainable competitive capacity and sustainable competitive position. At the same time, the article emphasizes that measuring the ability to compete in a sustainable manner is a complex task in which the pursuit of decoupling economic growth from pressure on the natural environment should be sought. In accordance with the strong principle of sustainability, which assumes the complementarity of various orders that form the overall concept of sustainable development, it has been assumed that each area of sustainable competitive capacity as well as position are equally important. This also has consequences for measuring sustainable development and thus for assessing the ability of the surveyed countries to compete sustainably and to develop their position on the world market with a sustainable manner. In the current proposals to measure this issue, the indicators describing various orders of sustainable development were most often combined within one synthetic measure of development. However, the paper proposes their separate analysis and the determination of the results achieved by the EU countries examined separately for each specified areas. This type of approach has not been used in current proposals of measurement of sustainable competitiveness. The solutions presented in the literature by averaging the results obtained in individual areas distorted the real picture of relationships between the areas that should be included in the overall model of sustainable competitiveness. The new approach to assessing sustainable competitiveness completely changes the perception of the results achieved by EU countries. This is also confirmed by the research results presented in the paper, which provide answers to the research questions regarding the strength of the relationship between the components forming the overall concept of sustainable competitiveness, the changes occurring between these relationships in 2016 compared to 2008 , and the similarity in development in all the analyzed areas of sustainable competitiveness. At the current stage of development of EU countries, the relationship between the ability to compete in sustainable manner and the achieved competitive position is in many cases not strong, although its growth is observed in 2016 compared to 2008. In particular, significantly higher results in terms of economic, social and institutional and political de- 
velopment are visible in the case of countries located in Northern and Western Europe, and less developed countries of Southern and Eastern Europe in this respect. However, in the case of environmental area these differences are much smaller. It is also worth noting that only countries such as: Denmark, Finland, Sweden and Estonia have managed to separate economic growth from its negative impact on the environment. There are also significant differences in the results of ordering EU countries in the area of sustainable competitive position. It should be emphasized that only in the case of Denmark; the results obtained in all analysed areas were the highest. This means that in the case of this country, the potential to compete in a sustainable way is confirmed by the results in terms of sustainable competitive position. This is also one of the reasons for the significant diversity of EU countries in terms of similarity achieved in all distinguished areas. Despite the differences in the classification of the studied EU countries in the years 2008 and 2016, the impact of the location of countries in the geographical regions of Europe and direct neighborhood on the results achieved in the field of sustainable competitiveness is still visible.

The future directions of research have been supplemented at the end of "Conclusions" part. According to authors, the further steps of research could be dedicated to forecasting of the development of EU countries in the area of sustainable competitiveness. For this purpose, the econometric models verifying the relation between considered areas in more detailed manner can be estimated. The knowledge about the direction of development in the area of sustainable competitiveness in the case of current situations related to the pandemic and prevised slowdown of the economies of the world's countries have become more and more important. The current situation on the world's market probably may change the relation between the countries and their directions of development.

It is also necessary to emphasize that the obtained results of the rankings are the result of the division of indicators into groups adopted by the authors, describing, e.g. the ability to compete sustainably in a social, economic dimension, etc. With a different distribution of these indicators, the obtained results may be different. The research results presented in the paper can be applied as a starting point to carry out more detailed analysis regarding the discrepancies in the level of sustainable competitiveness of particular Member states and consequently, diversification of the opportunities and requirements presented by EU countries' policy in this area.

\section{Funding}

The project is financed within the framework of the program of the Minister of Science and Higher Education under the name "Regional Excellence Initiative" in the years 2019-2022, project number 001/RID/2018/19, the amount of financing PLN 10,684,000.00 and by the Institute of Management, University of Szczecin, statutory funds.

\section{Author contributions}

conceptualization: K.Ch., I.B. methodology: K.Ch., I.B. K. S-D; software: K.Ch., I.B.; validation: K.Ch. I.B., K.S-D.; formal analysis: K.Ch., I.B., K. S-D.; investigation: K.Ch., I.B., K. S-D.; 
resources: K.Ch., I.B., K. S-D.; data curation: K.Ch., I.B.; writing original draft preparation: K.Ch., I.B., K. S-D.; writing review and editing: K.Ch., I.B., K. S-D.; visualization: K.Ch., I.B., K. S-D.; supervision: K.Ch., I.B. K. S-D.; project administration: K.Ch., I.B., K. S-D.; funding acquisition: K.Ch., I.B., K. S-D.

\section{Disclosure statement}

Authors don't have any competing financial, professional, or personal interests from other parties.

\section{References}

Aiginger, K., Bärenthaler-Sieber, S., \& Vogel, J. (2013). Competitiveness under new perspectives (Working Paper, No. 44). www.foreurope.eu

Aiginger, K., \& Vogel, J. (2015). Competitiveness: from a misleading concept to a strategy supporting Beyond GDP goals. Competitiveness Review, 25(5), 497-523. https://doi.org/10.1108/CR-06-2015-0052

Ajanovic, A. (2014). Promoting environmentally benign electric vehicles. Energy Procedia, 57, 807-816. https://doi.org/10.1016/j.egypro.2014.10.289

Atif, S. M., Srivastav, M., Sauytbekova, M., \& Arachchige, U. K. (2012). Globalization and Income Inequality: A Panel Data Analysis of 68 Countries. ZBW - Deutsche Zentralbibliothek für Wirtschaftswissenschaften, Leibniz Informations zentrum Wirtschaft, Kiel und Hamburg. http://hdl.handle.net/10419/65664

Balkyte, A., \& Tvaronavičienė, M. (2010). Perception of competitiveness in the context of sustainable development: Facets of "sustainable competitiveness". Journal of Business Economics and Management, 11(2), 341-365. https://doi.org/10.3846/jbem.2010.17

Berger, T. (2008). Concepts ofnational competitiveness. Journal of International Business and Economy, 9(1), 91-111.

Bilbao-Osorio, B., Blanke, J., Companella, E., Crotti, R., \& Drzeniek, M. (2013). Assessing the sustainable competitiveness of nations. In The global competitiveness report 2013-2014 (pp. 53-82). World Economic Forum. http://www3.weforum.org/docs/WEF_GlobalCompetitivenessReport_2013-14.pdf

Blanke, J., Crotti, R., Drezniek Hanouz, M., Fidanza, B., \& Thierry, G. (2011). The long term view: Developing a framework for assessing sustainable competitiveness. In The global competitiveness report 2011-2012 (pp. 51-74). World Economic Forum. http://reports.weforum.org/global-competitiveness-2011-2012/

Borys, T., \& Czaja, S. (2009). Research on sustainable development in Polish research centers/ Badania nad zrównoważonym rozwojem w polskich ośrodkach naukowych. In D. Kiełczewski (Ed.), Od koncepcji ekorozwoju do ekonomii zrównoważonego rozwoju [From the concept of eco-development to the economy of sustainable development]. Wydawnictwo Wyższej Szkoły Ekonomicznej w Białymstoku.

Calabrese, A., Costa, R., Levialdi, G. N., \& Menichini, T. (2019). Materiality analysis in sustainability reporting: a tool for directing corporate sustainability towards emerging economic, environmental and social opportunities. Technological and Economic Development of Economy, 25(5), 1016-1038. https://doi.org/10.3846/tede.2019.10550 
Cheba, K. (2019). Zrównoważona międzynarodowa konkurencyjność krajów Unii Europejskiej. Studium teoretyczno-empiryczne [Sustainable international competitiveness of EU countries. Theoretical and empirical study]. CeDeWu.

Cheba, K., \& Bąk, I. D. (2019). The application of multi-criteria taxonomy to comparative analysis of structures of sustainable development. Acta Universitatis Lodziensis. Folia Oeconomica, 5(344), 29-48. https://doi.org/10.18778/0208-6018.344.03

Cheba, K., \& Szopik-Depczyńska, K. (2019). Sustainable competitiveness and responsible innovations the case of the European Union Countries. Research Papers of the Wroclaw University of Economics, 549, 139-150. https://doi.org/10.15611/pn.2019.6.11

Corrigan, G., Crotti, R., Drzeniek, M., \& Serin, C. (2014). Assessing progress toward sustainable competitiveness. In The Global Competitiveness Report 2014-2015. World Economic Forum, Geneva.

Čiegis, R., Grundey, D., \& Štreimikiene, D. (2005). Economic aspects of cities sustainable development strategic planning. Technological and Economic Development of Economy, 11(4), 260-269.

https://doi.org/10.3846/13928619.2005.9637706

Del Río, P., Carrillo-Hermosilla, J., Könnölä, T., \& Bleda, M. (2016). Resources, capabilities and competences for eco-innovation. Technological and Economic Development of Economy, 22(2), 274-292. https://doi.org/10.3846/20294913.2015.1070301

Eurostat. (2018). Retrieved December, 2019, from http://ec.europa.eu/eurostat

Foxon, T. J., Pearson, P., Makuch, Z., \& Mata, M. (2005). Transforming policy processes to promote sustainable innovation: Some guiding principles (Report for policy-makers). ESRC Sustainable Technologies Programme, Imperial College London.

Grundey, D. (2008). Applying sustainability principles in the economy. Technological and Economic Development of Economy, 14(2), 101-106. https://doi.org/10.3846/1392-8619.2008.14.101-106

Guijarro, F., \& Poyatos, J. A. (2018). Designing a sustainable development goal index through a goal programming model: The case of EU-28 countries. Sustainability, 10(9), 3167. https://doi.org/10.3390/su10093167

Hämäläinen, T. J. (2003). National competitiveness and economic growth: The changing determinants of economic performance in the world economy. Edward Elgar Publishing Ltd.

Hellwig, Z. (1968). Zastosowanie metody taksonomicznej do typologicznego podziału krajów ze względu na poziom rozwoju oraz zasoby i strukturę wykwalifikowanych kadr [Application of the taxonomic method to the typological division of countries by level of their development as well as resources and structure of qualified personnel]. Przeglad Statystyczny, XV(4), 307-327.

Huggins, R., Izushi, H., \& Thompson, P. (2013). Regional competitiveness: Theories and methodologies for empirical analysis. Journal of CENTRUM Cathedra: the Business and Economics Research Journal, 6(2), 155-172. https://doi.org/10.7835/jcc-berj-2013-0086

Ketels, C. (2016). Review of competitiveness frameworks: An analysis conducted for the Irish National Competitiveness Council. Dublin. http://www.hbs.edu/

Kondyli, J. (2010). Measurement and evaluation of sustainable development: A composite indicator for the islands of the North Aegean region, Greece. Environmental Impact Assessment Review, 30(6), 347-356. https://doi.org/10.1016/j.eiar.2009.08.006

Kuc-Czarnecka, M. (2019). Sensitivity analysis as a tool to optimise Human Development Index. Equilibrium. Quarterly Journal of Economics and Economic Policy, 14(3), 425-440. https://doi.org/10.24136/eq.2019.020

Kukuła, K. (2000). Metoda unitaryzacji zerowanej [The zero-unitarization method]. Wydaw. Nauk. PWN. 
Lall, S. (2001). Competitiveness indices and developing countries: An economic evaluation of the global competitiveness report. World Development, 29(9), 1501-1525.

https://doi.org/10.1016/S0305-750X(01)00051-1

Leonard, D. R. P., Clarke, K. R., Somerfield, P. J., \& Warwick, R. M. (2006). The application of an indicator based on taxonomic distinctness for UK marine biodiversity assessments. Journal of Environmental Management, 78(1), 52-62. https://doi.org/10.1016/j.jenvman.2005.04.008

Littig, B., \& Griessler, E. (2005). Social sustainability: a catchword between political pragmatism and social theory. International Journal of Sustainable Development, 8(1-2), 65-79. https://doi.org/10.1504/IJSD.2005.007375

Lu, S. L., \& Sexton, M. (2008). The evolution of sustainable development. In M. Murray, \& A. Dainty (Eds.), Corporate social responsibility in the construction industry, (pp. 191-213). Taylor \& Francis. http://usir.salford.ac.uk/id/eprint/702/2/Sexton_Barrett_and_Lu.pdf

Malina, A. (2004). Multidimensional analysis of the spatial differentiation of the structure of the Polish economy by voivodships (translated from Polsh). Wydawnictwo AE w Krakowie.

Misala, J. (2011). Wielowymiarowa analiza przestrzennego zróżnicowania struktury gospodarki Polski według województw [International competitiveness of national economy]. PWE.

Młodak, A. (2006). Analiza taksonomiczna $w$ statystyce regionalnej [Taxonomic analysis in regional statistics]. Centrum Doradztwa i Informacji DIFIN.

Młodak, A., Józefowski, T., \& Wawrowski, Ł. (2016). Zastosowanie metod taksonomicznych w estymacji wskaźników ubóstwa [The use of taxonomic methods in estimating poverty indicators]. Wiadomości Statystyczne, LXI(2), 1-24. https://stat.gov.pl/czasopisma/wiadomosci-statystyczne/archiwum/ wiadomosci-statystyczne-nr-22016-657,7,11.html https://doi.org/10.5604/01.3001.0014.0900

Mori, K., \& Christodoulou, A. (2012). Review of sustainability indices and indicators: Towards a new City Sustainability Index (CSI). Environmental Impact Assessment Review, 32(1), 94-106. https://doi.org/10.1016/j.eiar.2011.06.001

Neter, J., Wasserman, W., \& Kutner, M. H. (1985). Applied linear statistical models: Regression, analysis of variance, and experimental designs. Richard D. Irwin, Inc. https://trove.nla.gov.au/work/17700595

Nowak, E. (1990). Taxonomic methods in the classification of socio-economic objects (translated from Polish). PWE.

Rogalska, E. (2018). Multiple-criteria analysis of regional entrepreneurship conditions in Poland. Equilibrium. Quarterly Journal of Economics and Economic Policy, 13(4), 707-723. https://doi.org/10.24136/eq.2018.034

Rutkauskas, A. (2008). On the sustainability of regional competitiveness development considering risk. Technological and Economic Development of Economy, 14(1), 89-99. https://doi.org/10.3846/2029-0187.2008.14.89-99

Scheurer, J. (2001). Urban ecology, innovations in housing policy and the future of cities: Towards sustainability in neighbourhood communities. Murdoch University.

Schrijver, N. J. (2008). The evolution of sustainable development in international law: inceptiom, meaning and status. The Pocket Books of The Hague Academy of International Law, 2. https://doi.org/10.1163/9789047444466

Shrivastava, P. (1995). Environmental technologies and competitive advantage. Strategic Management Journal, 16(S1), 183-200. https://doi.org/10.1002/smj.4250160923

Schwab, K., \& Sala-i-Martin, X. (2012). The global competitiveness report 2012-2013. World Economic Forum, Geneva. http://www3.weforum.org/docs/WEF_GlobalCompetitivenessReport_2012-13.pdf 
Siche, J. R., Agostinho, F., Ortega, E., \& Romeiro, A. (2008). Sustainability of nations by indices: Comparative study between environmental sustainability index, ecological footprint and the emergy performance indices. Ecological Economics, 66(4), 628-637.

https://doi.org/10.1016/j.ecolecon.2007.10.023

Stiglitz, J. E., Sen, A., \& Fitoussi, J. P. (2010). Report by the Commission on the Measurement of Economic Performance and Social Progress. Commission on the Measurement of Economic Performance and Social Progress, Paris, France. http://home.iscte-iul.pt/ apad/MTISext/didacticos/GPD\%20avaliax\%20Franca.pdf

Szopik-Depczyńska, K., Cheba, K., Bąk, I., Stajniak, M., Simboli, A., \& Ioppolo, G. (2018). The study of relationship in a hierarchical structure of EU sustainable development indicators. Ecological Indicators, 90, 120-131. https://doi.org/10.1016/j.ecolind.2018.03.002

Thalassinos, E., Cristea, M., \& Noja, G. G. (2019). Measuring active ageing within the European Union: Implications on economic development. Equilibrium. Quarterly Journal of Economics and Economic Policy, 14(4), 591-609. https://doi.org/10.24136/eq.2019.028

Vashisth, A., Kumar, R., \& Sharma, S. (2018). Major principles of sustainable transport system: A literature review. International Journal for Research in Applied Science \& Engineering Technology, 6(2). https://www.researchgate.net/publication/323336900_Major_Principles_of_Sustainable_Transport_System_A_Literature_Review

Velten, S., Leventon, J., Jager, N., \& Newig, J. (2015). What is sustainable agriculture? A Systematic review. Sustainability, 7(6), 7833-7865. https://doi.org/10.3390/su7067833

Zioło, M., Filipiak, B. Z., Bąk, I., \& Cheba, K. (2019). How to design more sustainable financial systems: The roles of environmental, social, and governance factors in the decision-making process. Sustainability, 11(20), 5604. https://doi.org/10.3390/su11205604 